\title{
Substitution Value of Cup Plant (Silphium perfoliatum L.) Silage in Dairy Cow Diet
}

\author{
Kun-Jun $\operatorname{Han}^{1} \&$ Kenneth A. Albrecht ${ }^{2}$ \\ ${ }^{1}$ School of Plant, Environmental, and Soil Sciences, Louisiana State University Agricultural Center, Baton Rouge, \\ Louisiana, USA \\ ${ }^{2}$ Department of Agronomy, University of Wisconsin-Madison, WI, USA \\ Correspondence: Kun-Jun Han, School of Plant, Environmental, and Soil Sciences, Louisiana State University \\ Agricultural Center, Baton Rouge, Louisiana, USA. Tel: 1-225-578-1305. E-mail: Khan@agcenter.lsu.edu
}

Received: August 24, $2021 \quad$ Accepted: September 25, $2021 \quad$ Online Published: October 15, 2021

doi:10.5539/jas.v13n11p1 URL: https://doi.org/10.5539/jas.v13n11p1

The research was partially supported by Hatch project 5168 and the University of Wisconsin-Madison College of Agriculture and Life Sciences.

\begin{abstract}
Cup plant (Silphium perfoliatum L.) may serve as an alternative perennial forage crop in lowlands of the north central United States. Three feeding trials were conducted with Holstein cows (Bos taurus) at the early, mid, and late lactation stages to evaluate the impact of different cup plant silage substitution levels for alfalfa (Medicago sativa L.)-corn (Zea mays L.) silage mixture on milking cow performance. The concentrations of lignin and CP (crude protein) in the first cut and regrowth cup plant silage were lower than alfalfa silage. Substituting one-half of the silage reduced voluntary dry matter (DM) intake of early lactation stage cows by $11 \%$. Although milk composition was not changed by the substitution, the 4\% FCM (fat corrected milk) production was reduced by $7.5 \%$. Another feeding trial tested substitution of one-third and two-thirds of the silage for mid-lactation cows. Increasing cup plant silage up to two-thirds of the forage portion in the diet reduced DM intakes and 4\% FCM production by 21.8 and $8.7 \%$, respectively. Milk composition did not change. Cow bodyweight was reduced as the substitution rate increased. Finally, a feeding trial with late-lactation cows indicated substitution of one-fourth of the silage performed equivalent in DM intake, milk composition, and milk production to those of cows fed a low forage diet ( $50 \%$ alfalfa-corn silage in diet), or a high forage diet ( $66 \%$ alfalfa-corn silage in diet) Based on the results of the three feeding trials, it is concluded that cup plant silage can substitute mixture of alfalfa-corn silage at up to $30 \%$ of the forage portion in diets without substantial negative impacts on the performance of dairy cows, especially during late lactation.
\end{abstract}

Keywords: Silphium perfoliatum, alfalfa, corn, silage, lactation

\section{Introduction}

Alfalfa (Medicago sativa L.) and corn (Zea mays L.) silages are the two primary forages in diets for lactating dairy cows in the north-central United States due to high crude protein (CP), or high energy concentrations. However, cropping systems based on alfalfa and corn silages are challenged on sites prone to intermittent flooding. Cup plant, a native perennial of wet to wet-mesic prairies of North America, is highly productive for biomass in soils too wet to maintain dependable production of alfalfa or corn (Albrecht \& Goldstein, 1997). Cup plant has demonstrated superior biomass production and has been singled out for strategic use on wet "foot-slopes" in eastern South Dakota (Zilverberg et al., 2016).

Cup plant biomass production reaches more than $20 \mathrm{Mg}$ DM/ha with a single harvest, and it has been promoted as an alternative to whole-plant corn for methane biogas production in Germany (Gansberger et al., 2015; Gerstberger et al., 2016). While research evaluating cup plant for forage utilization is limited, some research has documented potential feeding value as a silage crop with up to $240 \mathrm{~g} / \mathrm{kg} \mathrm{DM}$ of crude protein (CP) and $177 \mathrm{~g} / \mathrm{kg}$ DM of water-soluble carbohydrates (Douglas et al., 1987; Han et al., 2000b; Pichard, 2012; Kowalska et al., 2020). In Russia, CP concentration of cup plant declined from 210 to $140 \mathrm{~g} / \mathrm{kg}$ DM depending on the growth stage (Sokolov \& Gritsak, 1972). In Wisconsin USA, Albrecht and Bures (1999) studied the nutritive value 
changes of cup plant between bud and flowering growth stages. Cup plant harvested at the bud stage contained $130 \mathrm{~g} \mathrm{CP} / \mathrm{kg} \mathrm{DM}$ which was reduced to $96 \mathrm{~g} \mathrm{CP} / \mathrm{kg} \mathrm{DM}$ at the late flowering stage. However, the neutral detergent fiber (NDF) concentration did not substantially change from $478 \mathrm{~g} / \mathrm{kg} \mathrm{DM}$ at the bud stage through late flowering.

The digestibility of fresh cup plant was $661 \mathrm{~g} / \mathrm{kg} \mathrm{DM}$, while that of cup plant silage was $521 \mathrm{~g} / \mathrm{kg} \mathrm{DM}$ (Douglas et al., 1987). The in vitro true digestibility was around $700 \mathrm{~g} / \mathrm{kg} \mathrm{DM}$ and remained at that value even at the late-flowering stage (Albrecht \& Bures, 1999). Results from an in vitro study demonstrated that the DM digestion rate and the extent of the NDF digestion of cup plant were similar to those of alfalfa when compared at similar NDF concentrations, however, cup plant digestion occurred at a slower rate than alfalfa (Han et al., 2000a). Therefore, DM intake potential of cup plant can be lower than that of alfalfa. A study conducted with cup plant in southern Chile reported in vitro DM digestibility ranging from 610 to $780 \mathrm{~g} / \mathrm{kg}$ DM between the vegetative and seed-set stages (Pichard, 2012). Although the levels of CP, NDF, and digestibility need further evaluation to validate these results, the $\mathrm{CP}$ concentration and digestibility suggest that cup plant contains sufficient forage quality to be considered as a feed source for ruminant livestock.

In addition to the favorable $\mathrm{CP}$ and digestibility of cup plant, high biomass yield potential in a single harvest makes cup plant an attractive silage crop; however, thick stems and the moisture containing pith of cup plant require crushing the stem to speed the wilting process, which may cause some loss of nutritious leaves through mechanical damage. Limited research has investigated the feed value of cup plant in rations of ruminant livestock. Although the milk production cannot be compared to the current production in North America, Sokolov and Gritsak (1972) reported that cows fed cup plant silage produced 12\% more milk than cows fed corn silage. However, a feeding trial with yearling beef cattle in Wisconsin USA suggested a limit of $60 \%$ cup plant silage substitution for corn silage in mixed diets (Lehmkuhler et al., 2007).

Based on the limited feeding trial reports, cup plant may serve as an alternative perennial forage crop where conventional forage crops cannot be productive. There is little information on optimum proportion of cup plant silage in dairy cattle diets. Therefore, three feeding trials were conducted to determine the impact on lactation performance when portions of an alfalfa-corn silage mixture were replaced with cup plant silage in the test diets of lactating dairy cows.

\section{Methods}

\subsection{Forage Crop Production and Ensiling}

Cup plant derived from a synthetic population of seed collected in Wisconsin, Minnesota, Illinois, and Iowa was grown on Plano silt loam soil at the University of Wisconsin Arlington Agricultural Research Station near Arlington, Wisconsin. Approximately 0.5 ha of cup plant was established in $90 \mathrm{~cm}$ row space at a density of approximately 40,000 plants per ha 2 years before forage was harvested for the feeding trials. During this period, biomass was cut and removed from the field in late summer. Nitrogen fertilizer was applied at $150 \mathrm{~kg} / \mathrm{ha}$ each spring, and soil $\mathrm{P}$ and $\mathrm{K}$ were maintained at levels recommended for corn silage on that soil type. Cup plant foliage was cut with a New Idea model 5212 disk mower (AGCO, Georgia, USA) at the early bloom stage of maturity in mid-July, compressed through rubber rollers, and wilted for $30 \mathrm{~h}$ in the field. The wilted cup plant was chopped to a theoretical length of cut (TLC) of 1.5 to $2.0 \mathrm{~cm}$ and ensiled in plastic silo bags (Ag-Bag System, St. Nazianz, WI) for trials 1 and 2. In trial 3, cup plant second regrowth was harvested at the pre-bloom stage in October and ensiled as in trials 1 and 2.

The alfalfa used in all three trials was harvested at the bud stage and wilted to reach $350 \mathrm{~g} \mathrm{DM} / \mathrm{kg}$ before ensiling. Phosphorus and potassium were applied at $60 \mathrm{~kg} \mathrm{P}_{2} \mathrm{O}_{5}$ and $180 \mathrm{~kg} \mathrm{~K}_{2} \mathrm{O} /$ ha. Whole-plant corn was harvested between the $1 / 2$ and 3/4 starch milk line of the kernel (Wiersma et al., 1993) in mid-September, chopped to a TLC of $2.0 \mathrm{~cm}$, and ensiled. The DM concentrations of major ingredients in the diets were determined at the beginning of each trial to maintain the intended forage to concentrate ratios.

\subsection{Feeding Trials}

Three feeding trials were conducted with multiparous cows, weighing from 569 to $580 \mathrm{~kg}$ housed in a tie-stall barn at the Dairy Cattle Center located on the main campus of the University of Wisconsin, Madison. Cows were fed using individual pens twice a day $(0900$ and $1800 \mathrm{~h}$ ), and the amount of feed offered and orts were weighed daily for each cow. Daily milkings were made twice a day at 0700 and $1600 \mathrm{~h}$. All three trials were approved by the University of Wisconsin animal care and use committee. 
Table 1. Feed composition and feed value ( $\mathrm{g} / \mathrm{kg} \mathrm{DM})$ of diet (total mixed ration) treatments in the three feeding trials

\begin{tabular}{|c|c|c|c|c|c|c|c|c|}
\hline \multirow{3}{*}{ Item } & \multicolumn{8}{|c|}{ Diet treatment ${ }^{1}$} \\
\hline & \multicolumn{2}{|c|}{ Trial 1} & \multicolumn{3}{|c|}{ Trial 2} & \multicolumn{3}{|c|}{ Trial 3} \\
\hline & CONT & ${ }^{1 / 2}$ CUPS & CONT & ${ }^{1 / 3}$ CUPS & ${ }^{2 / 3}$ CUPS & LF & $\mathrm{HF}$ & ${ }^{1 / 4}$ CUPS \\
\hline Alfalfa silage & 232 & 116 & 224 & 149 & 75 & 243 & 324 & 220 \\
\hline Corn silage & 232 & 116 & 224 & 149 & 75 & 243 & 324 & 220 \\
\hline Cup plant silage & - & 232 & - & 149 & 298 & - & - & 132 \\
\hline Corn gluten meal & 126 & 126 & 83 & 83 & 83 & - & - & - \\
\hline Corn grain & 212 & 212 & 283 & 284 & 283 & - & - & - \\
\hline Animal fat & 19 & 19 & 9 & 9 & 9 & - & - & - \\
\hline Soybean meal (SBM) & 145 & 145 & 111 & 111 & 111 & 51 & 36 & 77 \\
\hline Blood meal & 10 & 10 & 9 & 9 & 9 & - & - & - \\
\hline Distiller grains & - & - & - & - & - & 40 & 41 & 44 \\
\hline High moisture corn & - & - & - & - & - & 308 & 162 & 176 \\
\hline Roasted SBM & - & - & - & - & - & 101 & 101 & 110 \\
\hline Corn grain meal & - & - & 36 & 36 & 36 & - & - & - \\
\hline Limestone & 14 & 14 & 13 & 13 & 13 & 7 & 3 & 11 \\
\hline Dicalcium phosphate & 4 & 4 & 4 & 4 & 4 & 4 & 5 & 4 \\
\hline Salt & 5 & 5 & 3 & 3 & 3 & 3 & 3 & 4 \\
\hline Vitamin. A, D, E & 1 & 1 & 1 & 1 & 1 & 1 & 1 & 1 \\
\hline \multicolumn{9}{|l|}{ Feed value of diet } \\
\hline $\mathrm{DM}$ & 703 & 658 & 667 & 655 & 642 & 511 & 558 & 501 \\
\hline $\mathrm{CP}$ & 202 & 191 & 168 & 162 & 165 & 153 & 153 & 157 \\
\hline aNDF & 252 & 264 & 260 & 275 & 290 & 277 & 332 & 290 \\
\hline $\mathrm{ADF}$ & 146 & 164 & 139 & 155 & 172 & 162 & 201 & 160 \\
\hline
\end{tabular}

Note. ${ }^{1}$ CONT: control diet containing alfalfa-corn silage in the forage portion at one half of total DM; ${ }^{1 / 2} \mathrm{CUPS}$ : diet with one-half of the forage portion replaced with cup plant silage; ${ }^{1 / 3}$ CUPS: diet with one-third of the forage portion replaced with cup plant silage; ${ }^{2 / 3}$ CUPS: diet with two-thirds of the forage portion replaced with cup plant silage; LF: diet with low forage proportion; HF: diet with high forage proportion; ${ }^{1 / 4}$ CUPS: diet with one-fourth of the forage portion replaced with cup plant silage.

${ }^{2}$ Contains vitamin $\mathrm{A}>3,300,000 \mathrm{IU} / \mathrm{kg}$, vitamin $\mathrm{D}>1,100,000 \mathrm{IU} / \mathrm{kg}$; vitamin $\mathrm{E}>11,000 \mathrm{IU} / \mathrm{kg}$.

A diet containing $500 \mathrm{~g} / \mathrm{kg} \mathrm{DM}$ as the forage portion comprising an equal amount of alfalfa silage and corn silage was replaced with selected proportions of cup plant silage in the feeding trials and balanced according to NRC (1989) with concentrate feed ingredients, minerals, and vitamins (Table 1). Therefore, nutrient compositions in the diets slightly differed in the diet treatments.

The CP concentrations in the diets were balanced to $190 \mathrm{~g} / \mathrm{kg}$ DM for early lactation cows (trial 1), $160 \mathrm{~g} / \mathrm{kg} \mathrm{DM}$ for-mid lactation cows (trial 2), and $150 \mathrm{~g} / \mathrm{kg} \mathrm{DM}$ for late lactation cows (trial 3) with corn gluten meal, soybean meal, and blood meal. The diet treatments were fed in the morning and afternoon. Milk yield, milk fat, and milk protein composition were measured for the last week of each experimental period. The amount of feed refusal, DM intake, and milk production were recorded daily for each cow. Milk and feed samples were collected twice a day for three consecutive days during the last week of each period.

\subsubsection{Trial 1}

The control diet (CONT) had a ratio of forage to concentrate of 46 to 54 , and the forage portion was formulated with a 50:50 mixture of alfalfa and corn silage. A diet replacing one-half of the forage portion with cup plant silage $\left({ }^{1 / 2} \mathrm{CUPS}\right.$ ) was compared to the control diet. Six multiparous Holstein cows in early lactation (between 1 and 80 DIM, days in milk) were randomly assigned to one of the two diet treatments in a $2 \times 2$ Latin square design with three replications. Feeding periods were $14 \mathrm{~d}$ consisting of $9 \mathrm{~d}$ of diet adaptation and $5 \mathrm{~d}$ of sample and data collection. 


\subsubsection{Trial 2}

The control diet (CONT) had a 45\% forage portion formulated with a 50:50 mixture of alfalfa and corn silage. Test diets replacing one-third $\left({ }^{1 / 3} \mathrm{CUPS}\right)$, or two-thirds $\left({ }^{2 / 3} \mathrm{CUPS}\right)$ of the forage portion with cup plant silage were fed along with the CONT treatment. Twelve multiparous Holstein cows in mid-lactation (between 81 and 150 DIM) were randomly assigned to one of the three diet treatments in a $3 \times 3$ Latin square design with four replications. Feeding periods of $21-\mathrm{d}$, consisted of $11 \mathrm{~d}$ of diet adaptation followed by $10 \mathrm{~d}$ for sample and data collection.

\subsubsection{Trial 3}

Three diet treatments containing low, intermediate, and high levels of forage proportions were prepared in the trial. The ${ }^{1 / 4}$ CUPS was a diet replacing one-fourth of the intermediate level of standard forage (50:50 alfalfa-corn silage mixture) portion with cup plant silage. Therefore, the trial compared impact of the increasing forage level in diet, and especially when replaced limited portion of the intermediate level of forage with cup plant silage. The forage to concentrate ratios in the diets were 50:50, 65:35, and 58:42 for low forage (LF), high forage (HF), and cup plant silage $\left({ }^{1 / 4}\right.$ CUPS) treatments, respectively. Nine multiparous Holstein cows in late-lactation (> 150 DIM) were randomly assigned to the diet treatments in a $3 \times 3$ Latin square design with three replications. Feeding periods were $21 \mathrm{~d}$, consisting of $11 \mathrm{~d}$ of diet adaptation followed by $10 \mathrm{~d}$ for sample and data collection.

\subsection{Analysis of Feed Samples}

Daily feed samples were prepared by treatment during each period. Subsamples of the diets were dried at $60{ }^{\circ} \mathrm{C}$ in a forced-air drying oven, and the dried feed samples were ground to pass a 1-mm screen with a Wiley Model 4 laboratory mill (Thomas Scientific, Swedesboro, NJ). A 1-g subsample was used to determine absolute DM by crucible drying in a $105{ }^{\circ} \mathrm{C}$ oven for three hours. The aNDF and ADF concentrations of these samples were determined by procedures of Robertson and Van Soest (1981) using alpha-amylase and sodium sulfite as described by Hintz et al. (1996). Cup plant silage samples were analyzed by the same procedure as other feed samples after pre-extraction with acetone to minimize filtration problems incurred. Lignin (sa) in feed samples was determined with ADF as an intermediate step through non-sequential analysis (Goering \& Van Soest, 1970). Total nitrogen $(\mathrm{N})$ analysis was determined by the semi-micro-Kjeldhal procedure (Bremner \& Breitenbeck, 1983), and CP was calculated as $\mathrm{N} \times 6.25$. Ash concentration was determined by modified AOAC 942.05 of Official Mehtods of Analysis (2005), igniting samples at $550{ }^{\circ} \mathrm{C}$ for 6 hours.

\subsection{Statistical Analysis}

Data obtained from feeding trials were analyzed using a mixed model analysis procedure of SAS (Littell et al., 1996) for replicated Latin square designs as the following model.

$$
Y_{I j k l}=\mu+\alpha_{i}+\beta_{j}+\gamma_{k}+\delta_{j}+\alpha \gamma_{i k}+\varepsilon_{i j k l}
$$

Where, $Y_{j j k l}=$ lactation performance, $\mu=$ overall mean, $\alpha_{i}=$ fixed effect of the diet treatment, $\beta_{j}=$ effect of period, $\gamma_{k}=$ effect of square, $\delta_{j}=$ effect of cow, $\alpha \gamma_{i k}=$ interaction between diet treatment and period, $\varepsilon_{i j k l}=$ residual error. The least-square means of diet treatment were compared using PDIFF as a test option. The significance of the mean difference was determined at $P<0.05$. The model considered treatment as a fixed effect; feeding period and cow were considered as random effects.

\section{Results}

\subsection{Nutrient Value of Forages}

Dry matter concentration of the first cut cup plant silage ranged from 275 to $295 \mathrm{~g} / \mathrm{kg}$ DM in trials 1 and 2 , indicating relatively high moisture concentration in cup plant even after the 30 hours of wilting (Table 2). Cup plant silage made with regrowth was wilted slightly more to attain a desirable DM range. Concentrations of aNDF in the first cut cup plant silage were greater than those in alfalfa silage or corn silage. However, the regrowth cup plant silage in trial 3 contained a lower fiber concentration than alfalfa silage. 
Table 2. Chemical composition of the forage in the lactating cow diets ( $\mathrm{g} / \mathrm{kg}$ DM unless stated otherwise)

\begin{tabular}{|c|c|c|c|}
\hline \multirow{2}{*}{ Item } & \multicolumn{3}{|c|}{ Forage } \\
\hline & Cup plant & Alfalfa & Corn \\
\hline \multicolumn{4}{|l|}{ Trial $1^{1}$} \\
\hline $\mathrm{DM}, \mathrm{g} / \mathrm{kg}$ & $275 \pm 14^{2}$ & $580 \pm 12.1$ & $358 \pm 10.0$ \\
\hline aNDF & $454 \pm 1.1$ & $412 \pm 3.2$ & $382 \pm 8.8$ \\
\hline $\mathrm{ADF}$ & $363 \pm 3.9$ & $343 \pm 28.9$ & $227 \pm 4.8$ \\
\hline Lignin (sa) & $36 \pm 3.9$ & $69 \pm 1.2$ & $22 \pm 0.9$ \\
\hline $\mathrm{CP}$ & $98 \pm 9.0$ & $216 \pm 2.4$ & $74 \pm 1.5$ \\
\hline Ash & $133 \pm 3.7$ & $107 \pm 3.7$ & $33 \pm 3.7$ \\
\hline \multicolumn{4}{|l|}{ Trial $2^{1}$} \\
\hline $\mathrm{DM}, \mathrm{g} / \mathrm{kg}$ & $295 \pm 7.5$ & $444 \pm 32.1$ & $317 \pm 26.0$ \\
\hline aNDF & $493 \pm 8.9$ & $396 \pm 9.3$ & $385 \pm 2.6$ \\
\hline $\mathrm{ADF}$ & $349 \pm 7.5$ & $268 \pm 8.0$ & $203 \pm 15.0$ \\
\hline Lignin (sa) & $40 \pm 4.2$ & $51 \pm 6.7$ & $14 \pm 3.6$ \\
\hline $\mathrm{CP}$ & $118 \pm 1.0$ & $250 \pm 2.4$ & $79 \pm 1.5$ \\
\hline Ash & $150 \pm 3.0$ & $121 \pm 3.0$ & $37 \pm 3.0$ \\
\hline \multicolumn{4}{|l|}{ Trial $3^{1-}$} \\
\hline $\mathrm{DM} \mathrm{g} / \mathrm{kg}$ & $305 \pm 1.5$ & $510 \pm 2.4$ & $385 \pm 7.5$ \\
\hline aNDF & $392 \pm 4.4$ & $415 \pm 14.5$ & $291 \pm 3.2$ \\
\hline $\mathrm{ADF}$ & $220 \pm 1.6$ & $311 \pm 8.6$ & $217 \pm 1.2$ \\
\hline Lignin (sa) & $41 \pm 0.6$ & $76 \pm 2.7$ & $28 \pm 3.2$ \\
\hline $\mathrm{CP}$ & $115 \pm 1.4$ & $241 \pm 3.7$ & $73 \pm 0.7$ \\
\hline Ash & $165 \pm 3.0$ & $104 \pm 3.0$ & $29 \pm 3.0$ \\
\hline
\end{tabular}

Note. ${ }^{1}$ In trials 1 and 2, the first growth cup plant was ensiled. In trial 3 second growth was ensiled.

${ }^{2}$ Values are mean \pm SE.

The ADF concentrations in cup plant were slightly higher or similar to those in alfalfa or corn silage. The lignin (sa) in cup plant silage ranged from 36 to $41 \mathrm{~g} / \mathrm{kg} \mathrm{DM}$, which is lower than alfalfa silage by $35 \mathrm{~g} / \mathrm{kg} \mathrm{DM}$, but greater than corn silage (Table 2). The CP concentrations in cup plant silage in the three trials were around 100 $\mathrm{g} / \mathrm{kg} \mathrm{DM}$, which was lower than in the alfalfa silage but higher than in the corn silage. Ash concentrations of cup plant silage ranged from 133 to $165 \mathrm{~g} / \mathrm{kg}$ DM (Table 2), which were greater values than the other two silages. The ash concentrations in cup plant silage were consistently higher than the other silages in the trials.

\subsection{Diet Intake and Lactation Performance}

\subsubsection{Trial 1}

Dry matter intake of cows fed ${ }^{1 / 2}$ CUPS was $2.7 \mathrm{~kg} / \mathrm{d}$ lower than intake of cows fed CONT (Table 3). Acid detergent fiber and aNDF intakes were also lower for cows fed ${ }^{1 / 2}$ CUPS $(P<0.01)$. Milk yield, milk fat percentage, and milk protein percentage were not different between CONT and ${ }^{1 / 2}$ CUPS. Therefore, milk fat and milk protein production did not differ. However, the 4\% FCM differed between cows fed CONT and those fed ${ }^{1 / 2}$ CUPS, and cows fed ${ }^{1 / 2}$ CUPS lost more bodyweight. 
Table 3. Cow performance on control diet containing alfalfa-corn silage in the forage portion (CONT), and test diet with one-half of the forage portion replaced with cup plant silage $\left({ }^{1 / 2} \mathrm{CUPS}\right)$ in Trial 1.

\begin{tabular}{|c|c|c|c|}
\hline \multirow{2}{*}{ Item } & \multicolumn{2}{|c|}{ Diet treatment } & \multirow{2}{*}{$\mathrm{SE}$} \\
\hline & CONT & ${ }^{1 / 2}$ CUPS & \\
\hline \multicolumn{4}{|l|}{ Intake, $\mathrm{kg} / \mathrm{d}$} \\
\hline $\mathrm{DM}$ & $24.1^{\mathrm{a} 1}$ & $21.4^{\mathrm{b}}$ & 0.73 \\
\hline $\mathrm{CP}$ & $4.9^{\mathrm{a}}$ & $4.1^{\mathrm{b}}$ & 0.15 \\
\hline $\mathrm{ADF}$ & $3.4^{\mathrm{a}}$ & $2.7^{\mathrm{b}}$ & 0.10 \\
\hline aNDF & $5.9^{\mathrm{a}}$ & $5.1^{\mathrm{b}}$ & 0.18 \\
\hline \multicolumn{4}{|l|}{ Lactation performance } \\
\hline Milk yield, $\mathrm{kg} / \mathrm{d}$ & 43.1 & 41.1 & 2.40 \\
\hline Milk fat, $\%$ & 3.5 & 3.4 & 0.13 \\
\hline Milk protein, $\%$ & 2.9 & 2.8 & 0.10 \\
\hline Milk fat yield, $\mathrm{kg} / \mathrm{d}$ & 1.5 & 1.4 & 0.11 \\
\hline Milk protein yield, $\mathrm{kg} / \mathrm{d}$ & 1.2 & 1.2 & 0.07 \\
\hline $4 \% \mathrm{FCM}^{2}, \mathrm{~kg} / \mathrm{d}$ & $40.1 \mathrm{a}$ & $37.1 \mathrm{~b}$ & 2.49 \\
\hline Bodyweight change $^{3}, \mathrm{~kg}$ & $-34.3 a$ & $-41.7 b$ & 1.90 \\
\hline
\end{tabular}

Note. ${ }^{1}$ Means within a row with different superscripts differ $(P<0.05)$.

${ }^{2}$ Fat corrected milk production.

${ }^{3}$ Bodyweight change during last 21 days.

\subsubsection{Trial 2}

Dry matter, $\mathrm{CP}$, aNDF, and ADF intakes decreased linearly $(P<0.05)$ as the cup plant silage in the diets increased (Table 4). Milk fat and milk protein composition were not affected by the proportion of cup plant silage.

Table 4. Cow performance on control diet containing alfalfa-corn silage in the forage portion (CONT), a test diet with one-third of the forage portion replaced with cup plant silage $\left({ }^{1 / 3} \mathrm{CUPS}\right)$, and a test diet with two-thirds of the forage portion replaced with cup plant silage $\left({ }^{2 / 3} \mathrm{CUPS}\right)$ in Trial 2

\begin{tabular}{lllll}
\hline \multirow{2}{*}{ Item } & \multicolumn{3}{c}{ Diet treatment } & \multirow{2}{*}{ SE } \\
\cline { 2 - 4 } & CONT & ${ }^{1 / 3}$ CUPS & ${ }^{2 / 3}$ CUPS \\
\hline Intake, $k g / d$ & $32.1^{\mathrm{a} 1}$ & $28.7^{\mathrm{b}}$ & $25.1^{\mathrm{c}}$ & 0.17 \\
$\mathrm{CP}$ & $6.7^{\mathrm{a}}$ & $5.7^{\mathrm{b}}$ & $4.7^{\mathrm{c}}$ & 0.23 \\
$\mathrm{ADF}$ & $5.3^{\mathrm{a}}$ & $4.2^{\mathrm{b}}$ & $3.7^{\mathrm{c}}$ & 0.21 \\
aNDF & $8.3^{\mathrm{a}}$ & $7.4^{\mathrm{b}}$ & $6.3^{\mathrm{c}}$ & 0.30 \\
\hdashline Lactation performance & & & & \\
Milk yield, $\mathrm{kg} / \mathrm{d}$ & $46.4^{\mathrm{a}}$ & $44.2^{\mathrm{b}}$ & $41.3^{\mathrm{c}}$ & 1.17 \\
Milk fat, \% & 3.6 & 3.5 & 3.4 & 0.14 \\
Milk protein, \% & 3.1 & 2.9 & 2.8 & 0.82 \\
Milk fat yield, $\mathrm{kg} / \mathrm{d}$ & 1.6 & 1.5 & 1.5 & 0.10 \\
Milk protein yield, $\mathrm{kg} / \mathrm{d}$ & $1.0^{\mathrm{a}}$ & $0.8^{\mathrm{b}}$ & $0.7^{\mathrm{c}}$ & 0.04 \\
$4 \%$ FCM ${ }^{2}, \mathrm{~kg} / \mathrm{d}$ & $42.5^{\mathrm{a}}$ & $40.7^{\mathrm{ab}}$ & $38.8^{\mathrm{b}}$ & 1.65 \\
Bodyweight change ${ }^{3}, \mathrm{~kg}$ & $24.4^{\mathrm{a}}$ & $6.6^{\mathrm{b}}$ & $-14.2^{\mathrm{c}}$ & 4.01 \\
\hline
\end{tabular}

Note. ${ }^{1}$ Means within a row with different superscripts differ $(P<0.05)$.

${ }^{2}$ Fat corrected milk production.

${ }^{3}$ Bodyweight change during last 21 days. 
However, milk yield decreased as cup plant silage proportion increased to the ${ }^{2 / 3} \mathrm{CUPS}$ treatment. The $4 \% \mathrm{FCM}$ of ${ }^{2 / 3} \mathrm{CUPS}$ was also lower than that of CONT. The cows on CONT and ${ }^{1 / 3} \mathrm{CUPS}$ gained weight, while those on ${ }^{2 / 3}$ CUPS lost weight (Table 4).

\subsubsection{Trial 3}

Dry matter intakes of ${ }^{1 / 4}$ CUPS did not differ from LF or HF (Table 5). The CP intake also did not differ among the diet treatments. Cows on HF had greater aNDF and ADF intakes than LF and ${ }^{1 / 4}$ CUPS due to the high fiber concentration in the diet treatment, which was followed by ${ }^{1 / 4}$ CUPS and LF. The production parameters milk yield, 4\% FCM, milk compositions, milk fat, and milk protein production were not different among the diet treatments. In all three diets, cows gained weight, and ${ }^{1 / 4} \mathrm{CUPS}$ gained the least.

Table 5. Cow performance fed on diets with low forage (LF), high forage (HF), and one-fourth of the forage portion substituted with cup plant silage $\left({ }^{1 / 4} \mathrm{CUPS}\right)$ in Trial 3

\begin{tabular}{|c|c|c|c|c|}
\hline \multirow{2}{*}{ Item } & \multicolumn{3}{|c|}{ Diet treatment } & \multirow{2}{*}{ SE } \\
\hline & LF & $\mathrm{HF}$ & ${ }^{1 / 4}$ CUPS & \\
\hline \multicolumn{5}{|l|}{ Intake, $\mathrm{kg} / \mathrm{d}$} \\
\hline DM & 20.8 & 21.8 & 20.7 & 1.59 \\
\hline $\mathrm{CP}$ & 3.6 & 3.6 & 3.6 & 0.07 \\
\hline $\mathrm{ADF}$ & $3.0^{\mathrm{c} 1}$ & $4.0^{\mathrm{a}}$ & $3.3^{\mathrm{b}}$ & 0.07 \\
\hline aNDF & $5.4^{\mathrm{c}}$ & $6.7^{\mathrm{a}}$ & $5.6^{\mathrm{b}}$ & 0.12 \\
\hline \multicolumn{5}{|l|}{ Lactation performance } \\
\hline Milk yield, $\mathrm{kg} / \mathrm{d}$ & 27.0 & 26.4 & 26.5 & 0.74 \\
\hline Milk fat, \% & 3.7 & 3.8 & 3.7 & 1.80 \\
\hline Milk protein, $\%$ & 3.4 & 3.3 & 3.3 & 0.16 \\
\hline Milk fat yield, $\mathrm{kg} / \mathrm{d}$ & 1.0 & 1.0 & 1.0 & 0.06 \\
\hline Milk protein yield, $\mathrm{kg} / \mathrm{d}$ & 0.9 & 0.9 & 0.9 & 0.03 \\
\hline $4 \% \mathrm{FCM}^{2}, \mathrm{~kg} / \mathrm{d}$ & 25.9 & 25.6 & 25.3 & 0.98 \\
\hline Bodyweight change ${ }^{3}, \mathrm{~kg}$ & $18.3^{\mathrm{b}}$ & $31.9^{\mathrm{a}}$ & $3.3^{\mathrm{c}}$ & 1.10 \\
\hline
\end{tabular}

Note. ${ }^{1}$ Means within a row with different superscripts differ $(P<0.05)$.

${ }^{2}$ Fat corrected milk production.

${ }^{3}$ Bodyweight change during last 21 days.

\section{Discussion}

As noted in the literature review, cup plant can serve as a buffer crop between fertile cropland and wetlands for years, capturing nutrients in runoff before they enter wetlands. Additionally, cup plant can serve as a wildlife crop because of its attractiveness to native pollinators and birds (Tuell et al., 2008). For these reasons, it is an ecologically attractive crop to incorporate into forage system in North America. As a native forb, cup plant has value as an alternative forage crop due to high biomass production potential and greater persistence than conventional forage crops on marginal land. With those merits, cup plant may serve as a forage crop if feeding value is proven for a range of ruminants.

The first growth of cup plant used in trials 1 and 2 was chopped and ensiled at marginally low levels of DM because of impending rain. The $\mathrm{pH}$ measurement of cup plant silage averaged near 6.0 in the study. The butyric acid and lactic acid concentrations in the cup plant silage averaged 2.24 and $2.45 \mathrm{~g} / \mathrm{kg} \mathrm{DM}$, respectively. Although the unconsumed cup plant silage was not quantified in the trials, a substantial proportion of orts were identified as cup plant silage. The high concentration of acetic acid (data not presented) could be the reason for the low DM intake of silage with cup plant substituted for alfalfa and corn silage in diets in trials 1 and 2. Since soluble sugar concentration in biomass ranged from 120 to $210 \mathrm{~g} / \mathrm{kg}$ DM (Daniel \& Rompf, 1994), fermentable sugar does not seem to be a limiting factor to lactic acid fermentation. The DM concentration in fresh cup plant biomass can be as low as 15\% (Douglas et al., 1987; Albrecht \& Goldstein, 1997; Daniel \& Rompf, 1994), wilting appears to be an essential step for this high yielding and high water containing biomass crop (Han et al., 2000b). However, in the Wisconsin climate, moisture reduction of biomass is always challenging. It can take 
several days to reach $300 \mathrm{~g} \mathrm{DM} / \mathrm{kg}$ even under full sun (Albrecht, unpublished data). Cup plant retains most of its moisture in thick stems, and mechanical conditioning is required at cutting to hasten the wilting process.

Compared with alfalfa or corn silage, the high fiber in cup plant silage is distinct. However, the higher fiber did not necessarily reason for low digestibility due to the different characteristics of the cell wall component (aNDF) in forage crops. Han et al. (2000a) reported a relatively slower increase of the lignin (sa) proportion in cup plant compared with the increase of aNDF, which was also confirmed through the lower lignin than alfalfa in the current study (Table 2). Since aNDF is a combined analytic value of cellulose, hemicellulose, lignin, mineral, and some detergent-insoluble nutrients, the actual digestibility of the forage should depend more on the indigestible portion rather than aNDF concentration. Maintaining relatively high in vitro true digestibility even at high aNDF reflects a moderate impact of increasing fiber on the digestibility of cup plant (Han et al., 2000a). Although lignin is a recalcitrant compound and demonstrates a particular relationship with indigestible aNDF in various forage crops (Van Soest et al., 2005; Raffrenato et al., 2018), the impact of lignin on digestibility differs across species, genetic background, and growth environment. The lignin proportions in aNDF of cup plant silage ranged from 8 to $10 \%$, while that of alfalfa ranged from 12 to $18 \%$ (Table 2). Relatively lower lignin (sa) concentration in cup plant silage compared to that in alfalfa silage may explain the greater digestibility potential of cup plant when compared with that of alfalfa at similar aNDF levels (Han et al., 2000a). Therefore, cup plant may provide a wider harvest window than conventional forage while maintaining digestibility. The range of CP concentration of cup plant reported in the literatures varies (Pichard, 2012; Daniel \& Rompf, 1994, Albrecht \& Goldstein, 1997). It was greater than that in corn silage by 2 to 4 percentage units in this study but lower than alfalfa silage. As a forage ingredient, Kowalska et al. (2020) indicated that cup plant can be an alternative forage option providing various amino acids and high $\mathrm{CP}$. The $\mathrm{CP}$ in the current cup plant silage ranged from 98 to 118 $\mathrm{g} / \mathrm{kg}$, and it was somewhat low, perhaps due to the leaf loss during the wilting process.

Greater mobilization of energy within the body likely occurred at the early lactation stage regardless of the nutrient intakes. Therefore, cows fed either the control or test diet in trial 1 lost body weight (Table 3). However, the replacement with cup plant reduced DM and nutrient intake and resulted in more weight loss. The linear increase $(P<0.05)$ of cup plant silage portion up to two-thirds of the forage portion in the test diet also caused increased suppression of DM intakes at the mid-lactation stage. However, milk production was maintained up to replacement of one-third of the alfalfa and corn silage with cup plant silage. According to the life cycle assessment on silages by Bernas et al. (2021), cultivation of cup plant targeting a replacement for corn-alfalfa silage at 33\% level could maintain similar dairy production levels as monoculture silages of the alfalfa or corn silage while yielding a lower environmental load. Moreover, the lower milk yield without significant concentration changes in milk fat and milk protein resulted in a linear decrease of milk protein yield and $4 \%$ fat corrected milk production in cows fed increasing cup plant silage proportions in the diet (Table 4). This was due to a depressed intake of DM with the inclusion of cup plant silage. The low DM intake of cup plant silage is probably related to weak fermentation and some secondary compounds. There should be some improvement in cup plant preservation to enhance the palatability of the silage.

Cup plant is also known to contain a range of secondary compounds, including sesqui-, di-, and tri-terpenoids (Pcolinski et al., 1994). Reed (1997) reported that volatile terpenoids, even if non-toxic, can lower palatability due to a strong aroma. Thus, in addition to improving the fermentation of cup plant through wilting, the impact of secondary compounds on the utilization of cup plant should be clarified. Perhaps longer adjustment periods could overcome some of the reluctance of cows to consume cup plant silage. In trial 3, the intake and milk yield of cows given a diet containing regrowth cup plant silage at one-fourth of the forage portion were equivalent to those of cows fed a low fiber diet (Table 5). A beef cattle feeding trial with cup plant silage by Lehmkuhler et al. (2007) demonstrated that the average daily gain did not differ between the cattle fed $30 \%$ cup plant silage and those fed a $100 \%$ corn silage diet; however, DM intake and NDF digestibility decreased as cup plant silage was increased in the diet. In addition to the weak fermentation and potential secondary compound issues, longer lag time for ruminal digestion than alfalfa (Han et al., 2000a) may cause slower rumen passage of cup plant and contribute to the lower DM intake. The ash concentration in cup plant silage may also require another consideration for the lower intake.

Considering its feeding value, cup plant should replace no more than $30 \%$ of the conventional forage portion in diets of milking cows to avoid loss of milk production. Although there is potential for increased feed value with the improvement of ensiling quality, replacing conventional alfalfa-corn silage with cup plant silage should be carefully applied so as not to sacrifice the performance or body condition of milking cows. 


\section{Acknowledgements}

The authors thank Dr. Dave Combs for his contributions to the design of the feeding trial. The authors also thank Ed Bures and Sandy Trower for their technical assistance.

\section{References}

Albrecht, K. A., \& Bures, E. J. (1999). Long-term performance of cup plant as a forage crop. Agronomy abstracts (p. 144). ASA, Madison, WI.

Albrecht, K. A., \& Goldstein, W. (1997). Silphium perfoliatum L.: A North American prairie plant with potential as a forage crop. Proc. XVIII Int. Grassl. Cong., June 8-19, 1997 (ID NO. 1113). Winnipeg, Manitoba, and Saskatoon, Saskatchewan Canada.

Bernas, J., Bernasová, T., Gerstberger, P., Moudrý, J., Konvalina, P., \& Moudrý, J. (2021). Cup plant, an alternative to conventional silage from a LCA perspective. The International Journal of Life Cycle Assessment, 26, 311-326. https://doi.org/10.1007/s11367-020-01858-X

Bremner, J. M., \& Breitenbeck, G. A. (1983). A simple method for determination of ammonium in semimicro-Kjeldahl analysis of soils and plant materials using a block digester. Commun. Soil Sci. Plant Anal., 14, 905-913. https://doi.org/10.1080/00103628309367418

Daniel, P., \& Rompf, R. (1994). Possibilities and limits in the utilization of Silphium perfoliatum as a fodder plant, renewable raw material and a landscape conservation-plant. Agrobiol. Res., 47, 353-354.

Douglas, J. A., Follett, J. M., Halliday, I. R., Hughes, J. W., \& Parr, C. R. (1987). Silphium: preliminary research on a possible new forage crop for New Zealand. Proc. Ann. Conf. Agron. Soc. of New Zealand, 17, 51-53.

Gansberger, M., Montgomery, L. F. R., \& Liebhard, P. (2015). Botanical characteristics, crop management and potential of Silphium perfoliatum L. as a renewable resource for biogas production: A review. Ind. Crops Prod., 63, 362-372. https://doi.org/10.1016/j.indcrop.2014.09.047

Gerstberger, P., Asen, F., \& Hartmann, C. (2016). Economy and ecology of cup plant (Silphium perfoliatum L.) compared with silage maize. J. Cult. Plants, 68, 372-377.

Goering, H. K., \& Van Soest, P. J. (1970). Forage fiber analyses (Apparatus, Regents, Procedures, and Some Applications). Agricultural Handbook No. 379. US. Gov. Print. Office, Washington, DC.

Han, K.J., Albrecht, K. A., Mertens, D. R., \& Kim, D. A. (2000a). Comparison of in vitro digestion kinetics of cup pla nt and alfalfa. Asian-Aus. J. Anim. Sci., 13, 641-644. https://doi.org/10.5713/ajas.2000.641

Han, K. J., Albrecht, K. A., Muck, R. E., \& Kim, D. A. (2000b). Moisture effect on fermentation characteristics of cup plant silage. Asian-Aus. J. Anim. Sci., 13, 636-640. https://doi.org/10.5713/ajas.2000.636

Hintz, R. W., Mertens, D. R., \& Albrecht, K. A. (1996). Effects of sodium sulfite on recovery and composition of detergent fiber and lignin. Journal of AOAC International, 79, 16-22. https://doi.org/10.1093/jaoac/79.1.16

Kowalska, G., Pankiewicz, U., \& Kowalski, R. (2020). Evaluation of chemical composition of some Silphium L. species as alternative raw materials. Agriculture, 10, 132. https://doi.org/10.3390/agriculture10040132

Lehmkuhler, J. W., Ramos, M. H., \& Albrecht, K. A. (2007). Cup plant silage as a replacement for corn silage in growing beef cattle diets. Forage \& Grazinglands. https://doi.org/10.1094/FG-2007-1107-01-RS

Littell, R. C., George, C., Milliken, A., Stroup, W. W., \& Wolfinger, R. D. (1996). SAS ${ }^{\circledR}$ System for mixed models. Cary, NC, SAS Institute Inc.

National Research Council. (1989). Nutrient requirement of dairy cattle (6th ed.). National Academy Press, Washington, D.C.

Official Methods of Analysis. (2005). AOAC International (Method 942.05, 18th ed.). Gaithersburg, MD.

Pcolinski, M.J., Doskotch, R.W., Lee, A.Y., \& Clardy, J. (1994). Chlorosilphanol A and silphanepoxol, labdane diterpenes from Silphium perfoliatum. J. Nat. Prod., 57, 776-783. https://doi.org/10.1021/np50108a014

Pichard, G. (2012). Management, production, and nutritional characteristics of cup plant (Silphium perfoliatum) in temperate climates of southern Chile. Cien. Inv. Agr., 39, 61-77. https://doi.org/10.4067/S0718-16202012 000100005

Raffrenato, E., Claassen, R., Erasmus, L., McNeil, D. M., Barber, D., Callow, M., \& Poppi, D. P. (2018). Prediction of indigestible NDF in South Africa and Australian forages from cell wall characteristics. Animal Feed Science and Technology, 246, 104-113. https://doi.org/10.1016/j.anifeedsci.2018.08.009 
Reed, J. D. (1997). Ecological biochemistry of secondary plant compounds in herbivore nutrition (Session 11, Constraints on animal production from forages and grasslands). Proc. XVIII Int. Grassl. Cong., June 8-19, 1997 (pp. 221-226). Winnipeg, Manitoba, and Saskatoon, Saskatchewan, Canada.

Robertson, J. B., \& Van Soest, P. J. (1981). The detergent system of analysis and its application to human foods. In W. P. T. James \& O. Theander (Eds.), The Analysis of Dietary Fiber in Food (pp. 123-158). Marcel Dekker, New York.

Sokolov, V. S., \& Gritsak, Z. I. (1972). Silphium: A valuable fodder and nectariferous crop. World Crops, 24, 299-301.

Tuell, J. K., Fiedler, A. K., Landis, D., \& Isaacs, R. (2008). Visitation by wild and managed bees (Hymenoptera: Apoidea) to eastern U.S. native plants for use in conservation programs. Environ. Entomol., 37, 707-718. https://doi.org/10.1603/0046-225X(2008)37[707:VBWAMB]2.0.CO;2

Van Soest, P. J., Van Amburgh, M. E., Robertson, J. B., \& Knaus, W. F. (2005). Validation of the 2.4 times lignin factor for ultimate extent of NDF digestion, and curve peeling rate of fermentation curves into pools. Proceedings of the Cornell Nutrition Conference (pp. 139-149). Syracuse, NY.

Wiersma, D. W., Carter, P. R., Albrecht, K. A., \& Coors, J. G. (1993). Kernal milkline stage and corn forage yield, quality, and dry matter content. J. Prod. Agric., 6, 94-99. https://doi.org/10.2134/jpa1993.0094

Zilverberg, C. J., Teoh, K., Boe A., Johnson, W. C., \& Owens, V. (2016). Strategic use of native species on environmental gradients increases diversity and biomass relative to switchgrass monocultures. Agric. Ecosyst Environ., 215, 110-121. https://doi.org/10.1016/j.agee.2015.09.006

\begin{abstract}
Abbreviations
aNDF: neutral detergent fiber after amylase treatment; ADF: acid detergent fiber; DIM: days in milk; Lignin (sa): sulfuric acid detergent lignin; CONT: control diet containing alfalfa-corn silage in the forage portion of total DM; ${ }^{1 / 2}$ CUPS: diet with one-half of the forage portion replaced with cup plant silage; ${ }^{1 / 3}$ CUPS: diet with one-third of the forage portion replaced with cup plant silage; ${ }^{2 / 3}$ CUPS: diet with two-thirds of the forage portion replaced with cup plant silage; HF: diet with high forage proportion; LF: diet with low forage proportion; ${ }^{1 / 4} \mathrm{CUPS}$ : diet with one-fourth of the forage portion replaced with cup plant silage.
\end{abstract}

\title{
Copyrights
}

Copyright for this article is retained by the author(s), with first publication rights granted to the journal.

This is an open-access article distributed under the terms and conditions of the Creative Commons Attribution license (http://creativecommons.org/licenses/by/4.0/). 